\title{
Antibacterial Properties of PEKK for Orthopedic Applications [Corrigendum]
}

Wang M, Bhardwaj G, Webster TJ. Int J Nanomedicine. 2017;12:6471-6476.

The authors have advised Figure 7 on page 6475 is incorrect. The authors inadvertently included a duplicate image for the live/dead Staphylococcus epidermidis and Pseudomonas aeruginosa PEEK samples shown in Figures 6 and 7, respectively. The correct Figure 7 is as follows.
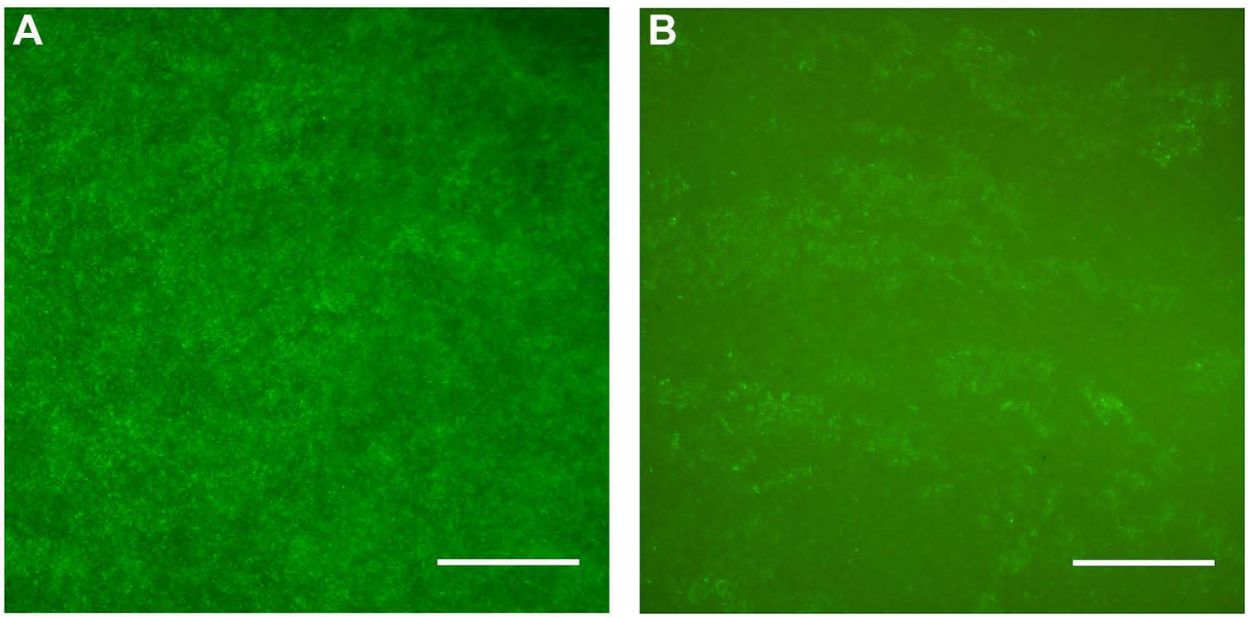

Figure 7 Live/dead assay of Pseudomonas aeruginosa attached on (A) PEEK and (B) PEKK samples (SYTOß 9 and propidium iodide respectively stained live [green] and dead [red] bacteria cells).

Notes: No red stained bacteria observed in these images. Scale bars $=50$ microns.

Abbreviations: PEEK, poly-ether-ether-ketone; PEKK, poly-ether-ketone-ketone.

\section{Publish your work in this journal}

The International Journal of Nanomedicine is an international, peerreviewed journal focusing on the application of nanotechnology in diagnostics, therapeutics, and drug delivery systems throughout the biomedical field. This journal is indexed on PubMed Central, MedLine, CAS, SciSearch ${ }^{\mathbb{B}}$, Current Contents ${ }^{\mathbb{R}} /$ Clinical Medicine,
Journal Citation Reports/Science Edition, EMBase, Scopus and the Elsevier Bibliographic databases. The manuscript management system is completely online and includes a very quick and fair peer-review system, which is all easy to use. Visit http://www.dovepress.com/ testimonials.php to read real quotes from published authors. 